Article

\title{
Trade Balance Effects on Economic Growth: Evidence from European Union Countries
}

\author{
Deimante Blavasciunaite, Lina Garsviene and Kristina Matuzeviciute * \\ Institute of Regional Development, Šiauliai University, Šiauliai 76285, Lithuania; \\ deimante.blavasciunaite@su.lt (D.B.); lina.garsviene@su.lt (L.G.) \\ * Correspondence: kristina.matuzeviciute@su.lt; Tel.: +370-41595885
}

Received: 12 March 2020; Accepted: 16 June 2020; Published: 1 July 2020

\begin{abstract}
A growing number of recent research analyse the trade balance impact on economic growth. However, ambiguous results of studies imply the need for the research as the deteriorating trade balance hinders economic growth. This research aims to investigate the impact of the trade balance on economic growth as well as to evaluate it during the periods of trade deficit. Our estimations are based on the European Union (EU) 28 countries panel data over the period of 1998-2018, using the OLS method of multivariate regression analysis with fixed effects and focusing on two strategies: (i) including all trade balance periods, and (ii) adding deficit dummy variable seeking to evaluate whether during deficit periods we can find different and significant effect on economic growth. Evaluating all trade balance periods, the obtained results indicate the negative and lagging impact of the trade balance on economic growth, and no significant differences of the impact were identified during the deficit periods. The deterioration of trade balance reduces average economic growth and from linear relationship evaluation, we can state that it does not matter whether it starts from trade deficit or surplus result. The results obtained may also obscure the possibility of a non-linear effect, which would suggest a stronger negative impact on economic growth when the trade balance deteriorates in the presence of a large trade deficit. When discussing directions for further research it would make sense to consider other factors, such as the size of the deficit and its permanence.
\end{abstract}

Keywords: economic growth; trade balance; panel estimates

JEL Classification: C23; F40; F43

\section{Introduction}

The integration of countries into the world economy is often seen as an important factor of the increasing income and growth. International trade boosts the global economy and at the same time can become an important driver of the country's economic growth. International trade promotes efficient resource allocation, enables a country to realize economies of scale, facilitates knowledge diffusion, promotes technological progress, and fosters competition in domestic and international markets, leading to production processes optimization and new product development.

Substantial attention has been paid to the examination of trade balance effects on economic growth as it becomes an important indicator of a country's competitiveness and is important in assessing the country's economy and its relations with the rest of the world (Topalli and Dogan 2016; Kang and Shambaugh 2016; Akbas and Lebe 2015). Previous studies mostly show positive results of trade impact on economic growth (Michelis and Zestos 2004; Awokuse 2007, 2008; Andersen and Babula 2009; Cetintas and Barisik 2008; Sun and Heshmati 2010; Busse and Königer 2012; Bakari 2017; Bakari et al. 2019a, 2019b), while others indicate a negative result of trade deficit (Abbas and Raza 2013; Bakari and Tiba 2019) or no effect (Bakari and Tiba 2019). 
Despite the strong interest, the impact of the trade balance on economic growth in the context of the European Union countries has not been extensively studied (Michelis and Zestos 2004; Awokuse 2007; Bakari 2017). To fill this gap, our paper aims to supplement the existing literature on estimated impact of trade in a few ways: (i) since most of the previous studies have been carried out in developing countries or at a single country level, our paper examines 28 European Union countries; (ii) our research includes 21-year data (1998-2018) to assess the impact of the trade balance on economic growth in the long-term; (iii) the majority of studies (Awokuse 2007, 2008; Cetintas and Barisik 2008; Bakari and Mabrouki 2017; Bakari 2017) investigate the effects on the economic growth of both export and import separately; also the authors (Sun and Heshmati 2010) studied the effects using only the export indicator, and there were also authors (Abbas and Raza 2013) who only examined the effect of trade deficit on economic growth or the combined effects of trade balance (surplus and deficit) (Busse and Königer 2012). Therefore, this study analyses the trade balance effects on economic growth in terms of the periods according to the trade balance result (deficit or surplus). The research analyses whether the effect of trade balance on economic growth differs evaluating its result of trade balance (deficit or surplus).

The rest of the paper is organized as follows: Section 2 presents a literature review. Section 3 discusses the research model. Section 4 presents the estimation results and discussion. The last section concludes the paper.

\section{Theoretical Background of the Trade Balance Impact on Economic Growth}

The assessment of the trade balance impact is widely discussed in the scientific literature. Economic theory identifies well-known channels through which trade can influence economic growth: trade promotes efficient resource allocation, enables the country to realize economies of scale, facilitates knowledge diffusion, promotes technological advancement as well as fosters competition in domestic and international markets and new product development. Andersen and Babula (2009) identified the channels through which international trade may affect the economic growth: (i) it provides access to foreign intermediates and technologies; (ii) it facilitates the dissemination of knowledge internationally; (iii) it expands the market size for new product varieties. The Thirlwall Law defines the traditional explanation of why the trade balance should be linked to economic growth (Thirlwall 1979). The balance of payment (BOP) constrained growth model states that actual growth can be projected on the basis of the ratio of export growth to import demand income elasticity, and that BOP must be in equilibrium. The basic idea of Thirlwall model is that export performance and import behavior determine the long-term economic growth. Increasing foreign exchange revenue from export is the only sustainable way financing increasing imports caused by the expanding domestic activity. There were various attempts to test empirically the assumptions of Thirlwall model. Soukiazis et al. (2012, 2014a, 2014b, 2018) developed a model based on the assumption of Thirlwall Law testing in different countries (Portugal, Italy, Slovakia, Greece) and additionally taking into account internal imbalances (twin deficit), also that relative prices are not neutral for economic growth. Garcimartin et al. (2016) testing the sources of business cycle in the framework of BOP constrained growth. Alleyne and Francis (2008) extended the model including interest payments and net transfers as these variables are very important to development of developing countries. Kvedaras et al. (2020) contributed the analysis of BOP constrained growth model decomposing economic growth rates and a cyclical growth term caused by net capital inflows.

Empirical studies have strong evidence that international trade has a positive impact on economic growth by facilitating capital accumulation, modernization of industrial structure, technological and institutional progress. More specifically, increased imports of capital and intermediate products not available on the domestic market may increase the productivity of production (Sun and Heshmati 2010). Wagner (2007) stated that the promotion of increased export fosters more intense competition and improved productivity. In the export industry, learning-by-doing activities can be accelerated by the spread of knowledge and technology. In addition, the benefits of the trade are largely generated by the 
external environment, the proper trade policy, and the structure of trade. Extensive empirical studies have been conducted on the impact of the trade on economic growth. Prior to the 1960s, trade impact studies were conducted only in a few specific countries. The development of econometrics, based on a mathematical model, has been introduced to analyse the interactive effects of trade and economic growth. The focus is on the investigation of the causal link between trade and economic growth: whether economic growth is driven by trade or vice versa. We have revised a number of studies that assessed the impact of the trade balance on economic growth (see Appendix A), concluding that there is likely positive relationship between trade and economic growth.

Empirical studies have been conducted on cross-country and panel or individual country case. Among studies that analyse the causal relationship between trade and economic growth on individual country level mostly developing countries were analysed. Sun and Heshmati (2010) stated that international trade exerts a positive impact on China's economic growth, however, facing with low domestic absorptive capacity, deterioration trade conditions, the negative impact on the environment, trade friction with partners and uneven regional development. The research by Altaee et al. (2016) provided ARDL and ECM to investigate the long-run and the short-run effects of trade on economic growth. The results of their study show that export has positive impact on economic growth, however, import affects real GDP growth negatively in the Kingdom of Saudi Arabia. Bakari (2017) found that exports and imports are seen as the source of economic growth in Germany. Bakari and Mabrouki (2017) pointed out that exports and imports have no effect on Panamanian economic growth. Keho (2017) confirmed that foreign trade has positive effects on economic growth in Ivory Coast. Bakari et al. (2019a, 2019b) analysed the long-term and short-term relationship between exports, imports and economic growth in Brasilia and China. The positive effects of exports, however negative effects of imports, were found in both countries, pointing out the importance of exports to provide positive economic performance. Kumar (2020) has highlighted the positive spillover effects of India's trade on the economic growth of Bangladesh, Sri Lanka, Nepal, and Bhutan.

The second group of studies examines the relationship between trade and economic growth by applying cross-country or panel data. Michelis and Zestos (2004) determined Granger causality from export and import growth to GDP growth, pointing out that policies orientated only to export promotion can be inefficient. Awokuse (2007) stated that trade stimulates economic growth emphasising the role of export and import. Moreover, the study by Awokuse (2008) analysing three countries in Europe confirmed trade impact on economic growth as well. Cetintas and Barisik (2008) analysing 13 transition economies concluded that economic growth is likely affected by import demand growth. The study by Awokuse and Christopoulos (2019) examined the non-linear relationship between export and economic growth in five industrialized economies (Canada, Italy, Japan, the UK, and the US) noting that impact of export on economic growth is diminishing what allows to identify the threshold level when export is still beneficial for economic growth. Busse and Königer (2012), by developing a panel model for 108 countries (of which 87 are developing countries), stated that trade had a positive and significant effect on economic growth. The estimation results by Fetahi-Vehapi et al. (2015) in 10 South East European countries indicated positive effects of trade on economic growth conditioned by the initial income per capita and other explanatory variables, such as human capital and gross fix capital formation. Were (2015) investigated trade effects on economic growth for 85 developed, developing and least developed countries, showing that trade positively impacts economic growth in developed and developing countries, but insignificantly impacts it in the least developed countries. On the contrary, the study by Bakari and Tiba (2019) concluded that exports negatively affect economic growth and imports have no effect due to positive externalities related to technology transfer bias, financial capacities, human expertise, large market size, and spillover effect. Butkus and Seputiene (2018) included trade balance indicator analyzing debt threshold level (turning point) and its impact on economic growth. Their research shows that trade balance is a crucial factor affecting the threshold level.

Empirical evidence can be sensitive to the study periods and data sources chosen, as well as trade measurement. The majority of authors (see Appendix A) analysed the change in GDP as a dependent 
variable in their research. However, there is no consensus on the choice of independent variables. The empirical studies analysed distinguished three independent factors: trade balance, imports and exports. The authors used different variables to analyse the trade balance factor: trade volume as a share of GDP (Busse and Königer 2012; Fetahi-Vehapi et al. 2015; Were 2015; Keho 2017), trade deficit (Abbas and Raza 2013). The import factor was used by the authors (Michelis and Zestos 2004; Awokuse 2007, 2008; Cetintas and Barisik 2008; Velnampy and Achchuthan 2013; Altaee et al. 2016; Bakari and Mabrouki 2017; Bakari 2017; Bakari and Tiba 2019; Bakari et al. 2019a, 2019b; Kumar 2020). Other authors (Michelis and Zestos 2004; Awokuse 2007, 2008; Cetintas and Barisik 2008; Awokuse and Christopoulos 2019; Sun and Heshmati 2010; Velnampy and Achchuthan 2013; Altaee et al. 2016; Bakari and Mabrouki 2017; Bakari 2017; Bakari and Tiba 2019; Bakari et al. 2019a, 2019b) used the export variable. It can be concluded that there is no clear consensus on the inclusion of independent variables in the model of trade balance effects on economic growth, as it depends on the subjective purpose of the study and the theoretical approach chosen. As can be seen, there is a lack of studies analysing trade balance impact on economic growth in European countries, as well as it is important to include not only export or import separately but also to reveal trade balance. It is not uncommon for a country with high export volumes for a number of years to be confronted with even greater import flows, which, as a result of the overall trade deficit, lead to a steady outflow of cash flows each year. When assessing the economic significance and validity of international trade for a country or shaping its future trade policy, it is important to assess the impact of the trade balance on economic growth.

Summarizing all empirical studies analysed, we can conclude that the trade balance has significant impact on economic growth. The results of previous research may depend on analysis period, country policy, level of development, the source of data, the different units of measurement, and the statistical methods used. Thus, the question remains in what direction the changes in the trade balance affect the country's economic growth.

\section{Methodology}

The concept of this paper is related to the assumption that the international integration of country economic growth depends on the country's trade balance and its result-deficit or surplus which is in line with Velnampy and Achchuthan (2013), Fetahi-Vehapi et al. (2015), and Were (2015). The study aims to reveal the situation of a group of countries without focusing on the individual country's assessment, so 28 European Union countries have been selected for the study. According to Apostolakis et al. (2019), there is a strong financial interdependence among the Eurozone countries, but there is evidence of stronger interdependence among the countries of the same cluster. This research assesses the sensitivity of the economic growth to trade balance changes in this group, which is particularly important in the context of the increasing interrelation between countries. The research covers 28 EU countries between 1998 and 2018, ensuring the statistical reliability of the study and to consider the fact that including lagging variables entails the loss of many observations in the study. The data used in this work were obtained from the Eurostat database.

The study was carried out based on 1998-2018 period panel data because, according to Hsiao (2003), due to the greater number of degrees of freedom, greater variability, and lower collinearity, aggregate data models are more reliable than time series or cross-sections. Their use makes it possible to include a larger number of independent variables in a relatively short time series. Aggregate data allows controlling the heterogeneity of variables as well as to check the lagged effects. One of the most commonly used methods for estimating the dependence between variables using panel data employed in this research is the ordinary least squares (OLS) method, following Busse and Königer (2012), and Abbas and Raza (2013). The multivariate regression method was used to assess the impact of the trade balance, all estimates were calculated using stabilized residual error regression.

While assessing the impact of the trade balance on economic growth, additionally it was chosen to group the observations according to the trade balance result (deficit or surplus). Based on this, two models were created. The first model (Equation (2)) will analyse the impact of the trade balance 
on economic growth, considering all observations, whether the trade balance is in surplus or in deficit. The following model (Equation (3)) will group periods in which there was a trade deficit, i.e., with an import/export ratio higher than 1. Seeking to distinguish deficit periods from surplus periods, the balance deficit periods are coded 1 , surplus periods are coded 0 .

As the aim of the study is to assess the impact of the trade balance, rather than export or import, on economic growth, the trade balance was chosen as the main independent variable. The trade balance variable was expressed as an import-export ratio indicator ( $L d \_I m E x$ ) in order to avoid the impact of absolute figures on the results of the research. The trade balance indicator will be logarithmic to obtain the elasticity coefficients. The deficit of trade balance can be identified as a problem for every country facing it, especially when it lasts for several or more years. Many authors (Cooper 2007; Papadimitriou et al. 2008; Gabberty and Vambery 2014; Awan and Mukhtar 2019) regard the long-term trade deficit as one of the main factors slowing down economic growth. The study will use a dummy variable to proxy the trade balance result. The encoded variable is the trade deficit (Def), which will examine the periods of trade deficit, i.e., with Import / Export $>1$. The purpose of grouping is to assess whether the deficit periods are significant in assessing the impact of the trade balance on economic growth. It is hoped that differences in exposure between the general and deficit periods would be obtained, which would explain the significance of the trade result- the deficit. The trade deficit is expected to have a stronger and more negative impact on economic growth in periods of deficit. We focused to evaluate how the economic growth is affected by trade balance, as a final result of all possible international effects and interactions, such as international interconnectedness (Marfatia et al. 2020), spillover effects of international development on economic growth through trade (Marfatia 2016, monetary policy and capital flows channel Marfatia 2020).

The dependent variable, i.e., economic growth is expressed as an indicator of real GDP change. Because in most macroeconomic factors the effects of the phenomenon only appear after some time, it is appropriate to include lagging variables in the multivariate regression analysis. Lagging is an unavoidable feature of the interaction of all socio-economic processes, and here too, the resulting models include lagging independent variables. As economic growth was assumed to be affected by the trade balance of previous years, the average economic growth rates for $3, \ldots$ and 10 years were calculated, using real GDP per capita. The average economic growth for a given year will be calculated using Equation (1):

$$
\begin{aligned}
& \Delta R G D P_{((t+a) \text { year average })} \\
& =\frac{\ln ((t+a) \text { years RGDP per capita Eur })-\ln (t \text { years RGDP per capita Eur })}{(t+a)-1}
\end{aligned}
$$

where: $\triangle R G D P_{((t+a) \text { year average. })}$-average economic growth $(t+a)$ years; $t$ - year.

This average economic growth over the relevant periods is calculated to more accurately measure average economic growth. The trade balance of the current year is not expected to lead to the same period of economic growth - the effect is lagged. It should be observed that the trade balance for year $t$, with control variables, determines the future $(t+3 ; \ldots ; t+10)$ economic growth. The aim was to find out in which year the effect is the strongest. All independent variables are included in a given year $(t)$.

Real GDP per capita (ln_RGDP) is a logarithmic independent control variable, in chain linked volume gross domestic product per capita, in millions of Euros in country $i$. It approximates average economic growth in year $t$. This control variable will check if current economic growth is affecting the average economic growth for the year $(t+n)$.

The econometric model of the trade balance effect on economic growth included two benchmark indicators that proxy the main factors of economic growth: human capital ( $\left.l d \_L a b\right)$ and net capital (ld_Cap). According to Goldin (2016), human capital is defined as qualification and accumulated knowledge. Human capital is a direct contributor to labour productivity and a prerequisite for technological advancement, making human capital development a key source of economic growth. 
The size of the knowledge and the development of skills increase the share of output per employee, and it is difficult to quantify these benefits. Following Awokuse (2007, 2008), Malik et al. (2015), and Sun and Heshmati (2010), we use indicator of human capital, i.e., persons with higher education (ISCED) and/or working in science and technology, as a share from the total population. Capital is the basis of economic growth, and the growth of the modern economy is determined not by the quantity of capital but by its quality. Capital Indicator (ld_Cap) is Net capital as a percentage of GDP, which was also used by Awokuse $(2007,2008)$ and Sun and Heshmati (2010).

In the analysis of the impact of the trade balance on economic growth, two models were developed to test the statements summarized in this article. With the model I (see Equation (2)) we will evaluate if the impact of the trade balance on economic growth is lagging and is felt in later years. The current year's trade balance is expected to affect only later economic growth-the effect is lagged.

$$
\begin{aligned}
\Delta R G D P_{(i, t+n)}=\alpha+\theta_{t}+ & \beta_{1} \ln \left(\operatorname{RGDP}_{(i, t)}\right)+\beta_{2} \operatorname{ld}(\operatorname{ImEx}(i, t))+\beta_{3} \operatorname{ld}\left(\operatorname{Lab}{ }_{(i, t)}\right) \\
& +\beta_{4} \operatorname{ld}\left(\operatorname{Cap}_{(i, t)}\right)+\Delta u_{i, t}
\end{aligned}
$$

where $R G D P_{i,(t+n)}$ - is the gross domestic product per capita in chain linked volume, in millions of Euros in $i$ country in $(t+n)$ year. $\triangle R G D P_{i,(t+n)}$-represents the average economic growth in year $(t+n) ; \Delta R G D P_{i,(t+n)}$ - the dependent variable is the average economic growth in country $i$ in year $(t+n) ; \theta_{t}$-time dummy variables of $1999, \ldots, 2018$ year, allowing the intercept $(\alpha)$ to change over time is important in our analysis. Secular trends in the EU will cause economic growth rates in all Member States to change significantly over a year. It is important to allow the temporal part $(\propto)$ to change during the analysis; $\beta_{1} \ln R G D P_{(i, t)}$-logarithmic independent control variable, gross domestic product per capita in chain linked volume, in millions of Euros in country $i$ in year $t$. $\triangle R G D P_{i, t}$-approximate average economic growth in year $t$. This control variable will test whether current economic growth will affect the average economic growth for the year $(t+n) ; \operatorname{ImEx}(i, t)$-the ratio of imports to exports in country $i$ in year $t$. If $\operatorname{ImEx}>1$, this indicates a deficit, if $\operatorname{ImEx}<1$, it indicates a surplus; $\beta_{2} \operatorname{ld}\left(\operatorname{ImE} x_{(i, t)}\right)$-logarithmic differentiation of independent variable, import-export ratio; $\beta_{3} \operatorname{ld}\left(L a b_{(i, t)}\right)$ - logarithmic differentiation of independent control variable, skilled labour as a share of total population; $\beta_{4} \mathrm{ld}\left(\mathrm{Cap}_{(i, t)}\right)$-logarithmic differentiation of independent control variable, net capital as a share of GDP; $\beta_{1}, \beta_{2}, \beta_{3}, \beta_{4}$-are explained as elasticity coefficients, reflecting the impact of lagged economic growth, trade balance, labour and capital on average $(t+3 ; \ldots ; t+10)$ economic growth; $n$-delayed period; $i$-denotes the number of observed countries (28 EU countries); $t$-denotes the number of periods (21 years, between 1998 and 2018). In a panel approach we accounted for a cyclical pattern of growth by introducing time dummies and estimated models, using fixed effects to account for country individual effects. As the same cross-sectional units (EU Member States) appear in each time period, there is no need to control the factors that have constant distribution across time. Therefore, they will be eliminated using first difference transformation.

The second model (see Equation (3)) enables to evaluate if the trade deficit periods in countries are significant while assessing the effect of the trade balance on economic growth.

$$
\begin{gathered}
\Delta R G D P_{(i, t+n)}=\alpha+\theta_{t}+\beta_{1} \ln \left(R G D P_{(i, t)}\right)+\beta_{2} \operatorname{ld}(\operatorname{ImEx}(i, t))+\beta_{3} \operatorname{ld}\left(\operatorname{Lab}_{(i, t)}\right)+ \\
\beta_{4} \operatorname{ld}\left(\operatorname{Cap}_{(i, t)}\right)+\beta_{5}(\operatorname{Def})+\Delta u_{i, t}
\end{gathered}
$$

where $\beta_{5}(D e f)$ - is a dummy variable denoted by 1 if country $i$ has a trade deficit for year $t(\operatorname{ImEx}>1)$; $\beta_{5}$-is interpreted as an elasticity coefficient reflecting the effect of trade deficit periods on average $(t+3 ; \ldots ; t+10)$ economic growth. 


\section{Results and Discussion}

Analysing the European Union countries from 1998 to 2018, it was found that 8 countries had trade surplus for the whole analysed period: Belgium, Denmark, Germany, Ireland, Luxembourg, The Netherlands, Austria, and Sweden. Only 4 countries had a trade deficit for the whole period under review: Greece, Latvia, Romania and the United Kingdom. We could argue that trade surplus is a result that is seen as less risky and therefore more desirable result in countries. Total EU trade surplus 1998-2008 increased by as much as 3.5 times over the period-about 423 billion Euros. Meanwhile, the overall trade deficit of EU countries in that period was increasing, rising from 53 billion Euros to 251 billion Euros, about 4.7 times. However, from 2009 to 2018, the trade deficit tended to shrink to 66 billion Euros, i.e., about 3.8 times.

Before discussing the results of trade balance impact or changing trends, two concepts must be distinguished: trade balance deterioration-a situation in which the deficit is increasing or the surplus is decreasing; improvement of the trade balance - a situation when the deficit is decreasing or the surplus is increasing. Because the trade balance in this research is indicated as import-export ratio, we should define the possible results by discussing the cases. If we confirm the negative impact of trade balance on economic growth, the trade balance deterioration will lead to a slowdown in economic growth, otherwise in a case of positive impact, the trade balance deterioration leads to the acceleration of economic growth.

A comparison between the change of average trade balance and economic growth rate for 21 year-period is presented in Figure $1^{1}$.

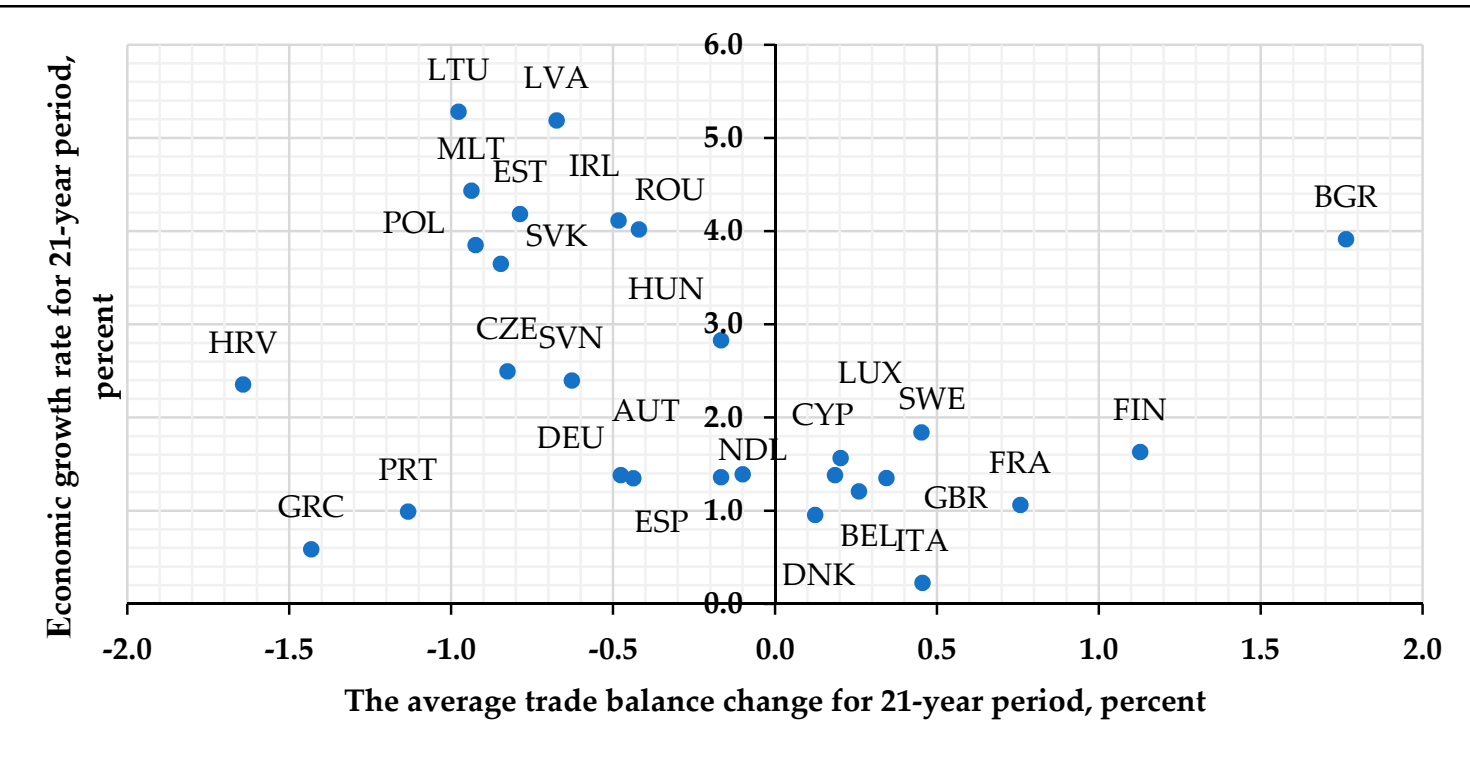

Figure 1. A comparison between the average trade balance change and economic growth rate for 21-year period.

Figure 1 indicates that in most countries (18 EU countries: LTU, LVA, MLT, EST, IRL, ROU, POL, SVK, HUN, CZE, SVN, HRV, DEU, AUT, NDL, ESP, PRT, GRC) the trade balance ratio is decreasing, and trade balance is improving, therefore, faster economic growth is noticeable. In a small number of

1 Country codes: BEL-Belgium, BGR-Bulgaria, CZE—the Czech Republic, DNK-Denmark, DEU-Germany, EST-Estonia, IRL-Ireland, GRC-Greece, ESP-Spain, FRA -France, HRV -Croatia, ITA -Italy, CYP-Cyprus, LVA-Latvia, LTU—Lithuania, LUX -Luxembourg, HUN-Hungary, MLT-Malta, NLD—The Netherlands, AUT-Austria, POL-Poland, PRT—Portugal, ROU—Romania, SVN—Slovenia, SVK—Slovakia, FIN—Finland, SWE-Sweden, GBR—the United Kingdom. 
countries (10 EU countries: BGR, LUX, CYP, SWE, DNK, BEL, ITA, GBR, FRA, FIN) the trade balance ratio is increasing, i.e., trade balance is deteriorating and the countries face slower economic growth.

Figure 2 compares the change in 10-year annual average trade balance with the economic growth rate in the EU-28 countries.

Even when analysing a shorter period (10 years), the situation does not change significantly, i.e., the countries were divided into four groups. The average 10-year data in Figure 2 shows that in the first group of countries (19 EU countries: IRL, BGR, ROU, LVA, LTU, POL, MLT, EST, SVC, HUN, CZE, PRT, ESP, HRV, SVN, GBR, DNK, FRA, NLD) trade balance ratio is decreasing, i.e., trade balance is improving and economic growth is noticeable. In the second group of countries (4 EU countries: DEU, BEL, AUT, SWE) the trade balance ratio is increasing, i.e., the trade balance is deteriorating and economic growth is slowing down. In the third group of countries (3 EU countries: GRC, CYP, ITA) the trade balance ratio is decreasing, i.e., trade balance is improving and economic growth is slowing down. In the fourth group of countries (2 EU countries: LUX, FIN) the trade balance ratio is increasing, i.e., the balance is deteriorating and economic growth is slowing down.

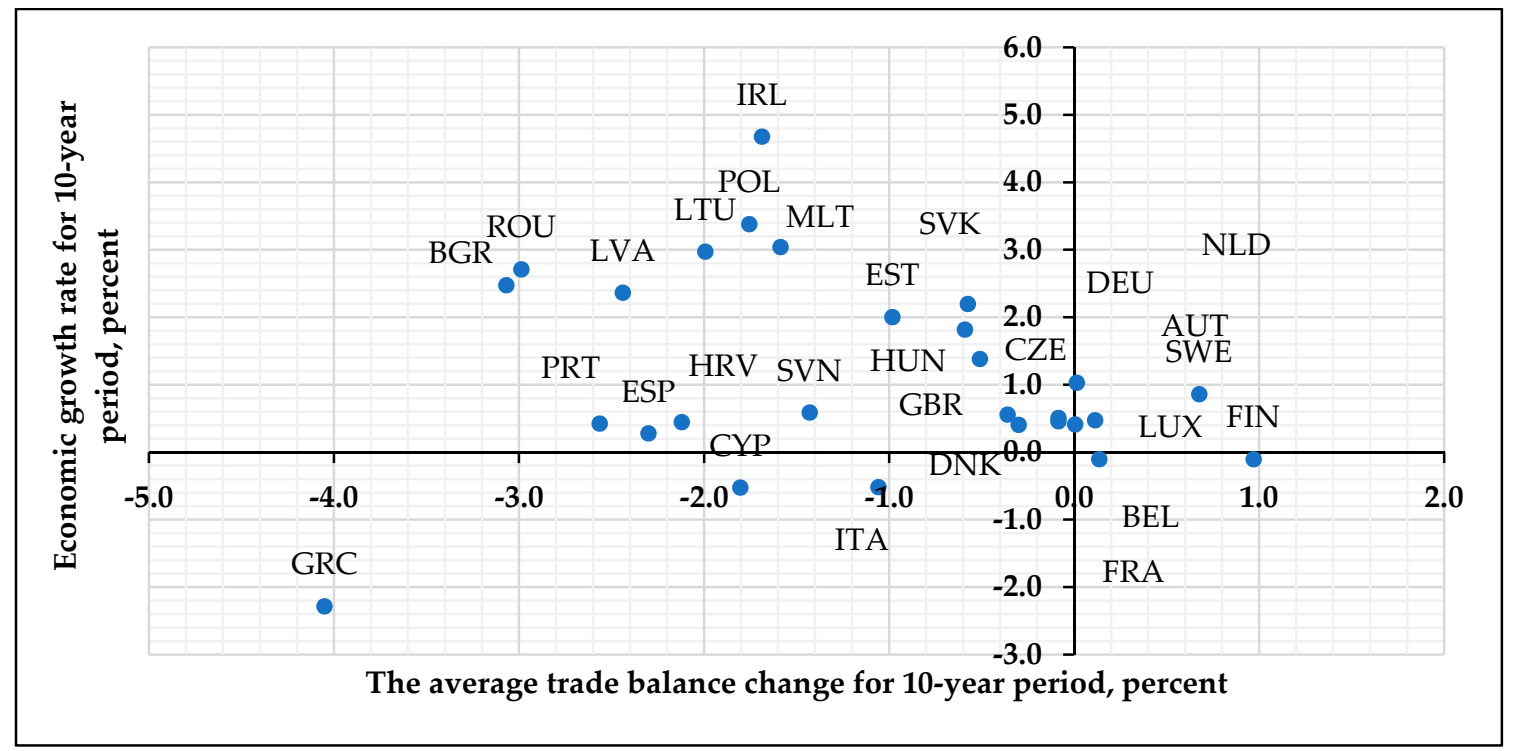

Figure 2. A comparison between the average trade balance change and economic growth rate for 10 -year period.

The results of the multivariate regression analysis of the first model, assessing the effect of the trade balance on economic growth, are presented in Table 1. This model (based on Equation (2)) tests whether the effect of the trade balance on economic growth is lagging and is obvious in later years. The first model contains 588 observations.

Table 1. Results of a multivariate regression analysis of trade balance effects on economic growth in EU countries (model I).

\begin{tabular}{|c|c|c|c|c|c|c|c|c|}
\hline & $3 Y$ & $4 Y$ & $5 Y$ & $6 Y$ & $7 Y$ & $8 Y$ & $9 Y$ & $10 Y$ \\
\hline const & $0.2180^{* * *}$ & $0.2475^{* * *}$ & $0.2651^{* * *}$ & $0.2732^{* * *}$ & $0.2786^{* * *}$ & $0.2822 * * *$ & $0.2737^{* * *}$ & $0.2530 * * *$ \\
\hline 1_RGDP & $-0.0245^{* * *}$ & $-0.0263^{* * *}$ & $-0.0271^{* * *}$ & $-0.0274^{* * *}$ & $-0.0275^{* * *}$ & $-0.0273^{* * *}$ & $-0.0266^{* * * *}$ & $-0.0253^{* * *}$ \\
\hline ld_ImEx & $-0.0452^{* * *}$ & $-0.0463^{* * *}$ & $-0.0447^{* * *}$ & $-0.0431^{* * *}$ & $-0.0426^{* * *}$ & $-0.0416^{* * *}$ & $-0.0397^{* * * *}$ & $-0.0374^{* * *}$ \\
\hline ld_Lab & $0.0115^{* * *}$ & $0.0137^{* * * *}$ & $0.0149^{* * *}$ & $0.0154^{* * *}$ & $0.0149^{* * *}$ & $0.0144^{* * * *}$ & $0.0138^{* * *}$ & $0.0124^{* * *}$ \\
\hline ld_Cap & 0.0046 & -0.0026 & -0.0070 & $-0.0096^{* *}$ & $-0.0113^{* * *}$ & $-0.0131^{* * * *}$ & $-0.0119^{* * *}$ & $-0.0081^{* *}$ \\
\hline
\end{tabular}

$* *, * *$ indicate statistically significant at the $5 \%$ and $1 \%$ levels, respectively. Model I-588 observations. $3 \mathrm{Y} ; . .$. ; $10 \mathrm{Y}-$ models reflecting the effect of trade deficit on periods on average $(t+3 ; \ldots ; t+10)$ economic growth. All estimations include time tummies. All models are estimated, using fixed effects to account for country individual effects. 
As shown in Table 1, the average economic growth is affected by the trade balance, labour, economic growth, and net capital (from the $6 \mathrm{Y}$ model). The results of multivariate regression analysis show that the trade balance has a statistically significant effect on economic growth. The trade balance ratio has a negative impact on economic growth, i.e., 1 percent increase in trade balance ratio (trade deficit grows or trade surplus decreases) reduces economic growth by about 0.04 percent on average. However, from the analysis, we can see that the effect of trade balance $\beta$ decreases with each following model, indicating that the trade balance has a stronger effect on 3-year average economic growth ( 0.0452 percent) than the impact on 10-year average growth ( 0.0374 percent).

Analysing the control variables (economic growth, labour and capital), it was observed that economic growth and labour were statistically significant in all 8 models (99 percent of significance level in all models). Based on the results of a multivariate regression analysis, it is possible to state that 1 percent increase in the labour variable increases the average economic growth by about 0.02 percent. As the economic growth variable increases by 1 percent, the average economic growth is reduced by about 0.03 percent. Capital was statistically insignificant in the first three models, but ranging from model 6Y to model 10Y, it was already statistically significant. Based on the results, it can be stated that if the capital variable increases by 1 percent, economic growth is reduced by about 0.01 percent. Analysing the model I (based on Equation (2)), we can state that the impact of the trade balance on economic growth is lagged and can be seen in later years, but the effect is deteriorated when analysed over the long term.

The results of the model II (based on Equation (3)) are discussed below. This model incorporates a dummy variable $\left(\beta \_5(D e f)\right)$, which is coded 1 if country $t$ has a trade deficit in year $t(\operatorname{ImEx}>1)$. It represents the effect of trade deficit periods on the average economic growth of $3, \ldots, 10$ years, respectively. This model provides 518 observations ( 269 of them are deficit observation). The results of the multivariate regression analysis of the model II, additionally assessing the effect of trade deficit on economic growth, are presented in Table 2. This model sought to determine if the impact of trade balance on economic growth differs while compering the impact on deficit periods considering with all periods (deficit and surplus). Also we test whether the trade deficit periods in countries are significant while assessing the effect of the trade balance on economic growth.

Table 2. Results of a multivariate regression analysis of trade balance effects on economic growth in EU countries (model II).

\begin{tabular}{|c|c|c|c|c|c|c|c|c|}
\hline & $3 Y$ & $4 Y$ & $5 Y$ & $6 Y$ & $7 Y$ & $8 Y$ & $9 Y$ & $10 Y$ \\
\hline const & 0.2902 *** & $0.3110^{* * *}$ & $0.3083^{* * *}$ & $0.3095^{* * *}$ & $0.3133^{* * *}$ & $0.3212 * * *$ & $0.3188^{* * *}$ & $0.3098^{* * *}$ \\
\hline 1_RGDP & $-0.0301^{* * * *}$ & $-0.0314^{* * *}$ & $-0.0317^{* * *}$ & $-0.0318^{* * *}$ & $-0.0319 * * *$ & $-0.0319 * * *$ & $-0.0318^{* * *}$ & $-0.0302^{* * *}$ \\
\hline 1d_ImEx & $-0.0313^{* * * *}$ & $-0.0352^{* * *}$ & $-0.0355^{* * *}$ & $-0.0341^{* * *}$ & $-0.0328^{* * *}$ & $-0.0325^{* * * *}$ & $-0.0299 * * *$ & $-0.0272^{* * *}$ \\
\hline 1d_Lab & 0.0150 ** & $0.0176^{* * * *}$ & $0.0186^{* * *}$ & $0.0186^{* * *}$ & $0.0179 * * *$ & $0.0170^{* * *}$ & $0.0159 * * *$ & $0.0144^{* * *}$ \\
\hline ld_Cap & -0.0049 & -0.0102 & $-0.0121^{* *}$ & $-0.0130 * * *$ & $-0.0137^{* * *}$ & $-0.0150 * * *$ & $-0.0158^{* * *}$ & $-0.0146^{* * *}$ \\
\hline Def & 0.0012 & 0.0022 & 0.0018 & 0.0013 & 0.0002 & 0.0002 & -0.0004 & -0.008 \\
\hline
\end{tabular}

$* *,{ }^{* * *}$ indicate statistically significant at the $5 \%$ and $1 \%$ levels, respectively. Model II-518 observations. 3Y;

$\ldots ; 10 Y-$ models reflecting the effect of trade deficit on periods on average $(t+3 ; \ldots ; t+10)$ economic growth. All estimations include time tummies. All models are estimated, using fixed effects to account for country individual effects.

As shown in Table 2, the average economic growth is affected only by four variables (excluding dummy variable Def). The inclusion of the dummy Def variable makes it possible to assess whether there is the difference of the effect of trade balance on economic growth in deficit periods compared to all periods. The dummy Def variable is insignificant in all model specifications. We did not find a significant effect of trade deficit periods while assessing the impact of the trade balance on economic growth.

As shown in Table 2, the trade balance has a negative impact on average economic growth. Based on the results of the multivariate regression analysis, it can be stated that the trade balance ratio increased by 1 percent (i.e., trade deficit increases), and the economic growth declines by about 
0.03 percent on average. However, from the analysis, we can see that the effect of trade balance on economic growth $\beta$ decreases with each model, showing that the trade balance has a stronger effect on 3-year average economic growth (0.0313 percent) than the impact on 10-year average growth (0.0272 percent).

The results of both models highlight the need for modelling the inherent nonlinearities, that would suggest a stronger negative impact on economic growth when the trade balance deteriorates in the presence of a large trade deficit. Reviewing the statistical sense of models, we can state, that all models satisfy all assumptions of regression model. The models were estimated, using fixed effects, also with robust standard errors (HAC).

Based on the results of the multivariate regression analysis, it can be stated that the increase of the labour variable by 1 percent leads to an increase in economic growth of about 0.02 percent on average. As the economic growth variable increases by $1 \%$, the average economic growth is reduced by about 0.03 percent. Capital was statistically insignificant in the first two models, but from the 3rd model to the 8 th model it was already statistically significant. An increase of $1 \%$ in the capital variable decreases the economic growth by 0.01 percent. Analysing the results of model II, we can state that the trade deficit periods are significant while assessing the impact of trade balance on economic growth.

Both I and II models (with all sub models) satisfy the assumptions of the validation, i.e., model errors are not correlated, independent variables are strongly correlated with the dependent variable. A multivariate regression analysis revealed a lag of the impact of the trade balance on economic growth, therefore, using the trade balance change and other obtained parameters, we will forecast the average expected economic growth for the period 2019-2021 in EU-28 countries (see Figure 3).

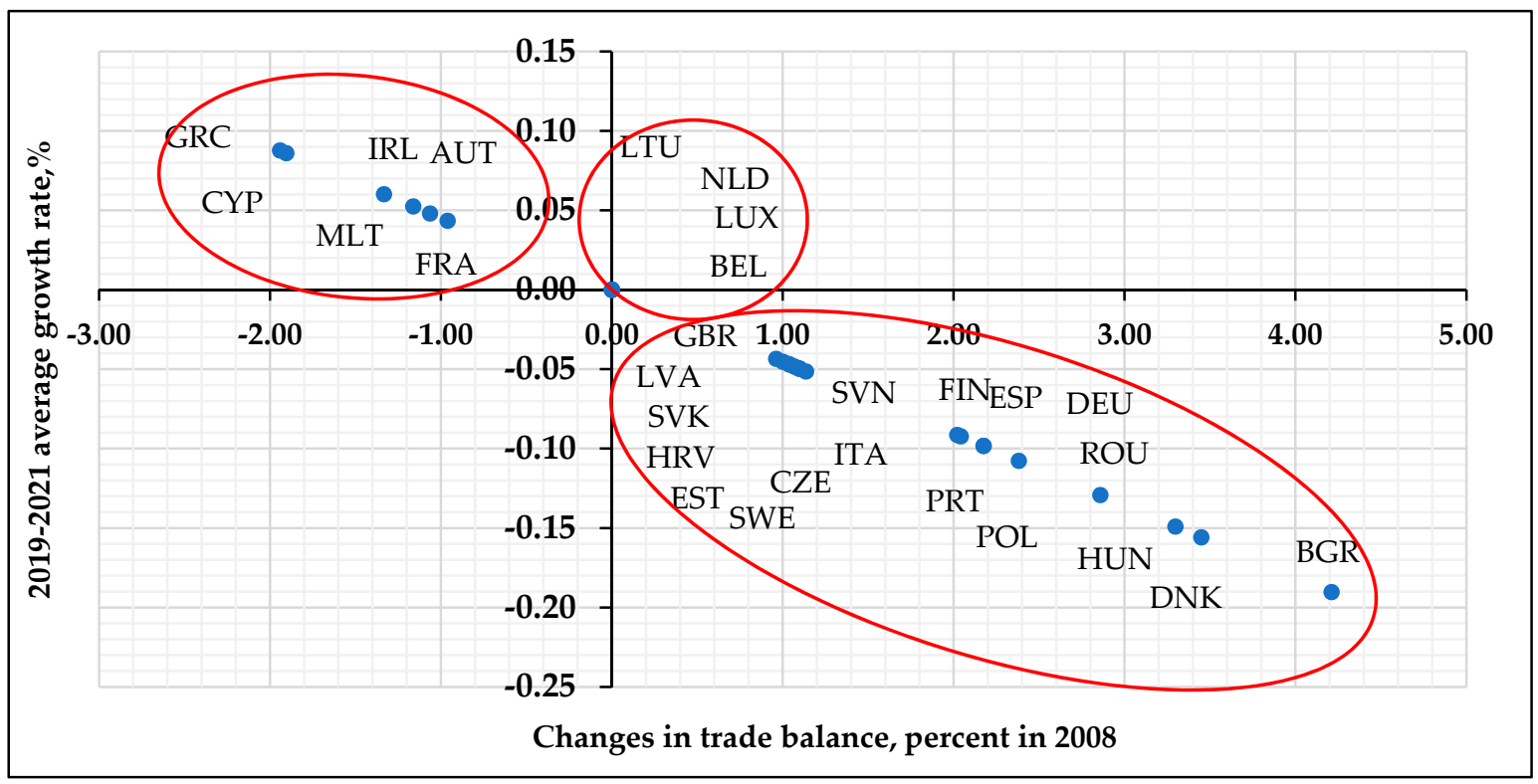

Figure 3. Changes in the trade balance in 2018 and economic growth rates, percent.

Figure 3 shows that the countries were divided into three groups. A positive average economic growth over the period 2019-2021 is forecast in six countries (GRC, CYP, IRL, AUT, MLT, FRA), when the trade balance is improving, i.e., either the surplus is increasing or the deficit is decreasing. In four countries (LTU, NDL, LUX, BEL), the situation of trade balance remained quite similar, so it should not lead to changes in average economic growth. In the remaining $18 \mathrm{EU}$ countries (GBR, LVA, SVK, HRV, EST, SWE, CZE, ITA, SVN, FIN, ESP, DEU, ROU, PRT, POL, HUN, DNK, BRG) because of deteriorating trade balance in 2018 (i.e., declining surplus or increasing deficit) in 2019-2021 there is a forecast decline in average economic growth. 


\section{Conclusions}

The previous studies provide evidence on the impact of the trade balance on economic growth, however, the results are ambiguous. This raises the need to determine the importance of trade balance on economic growth as it is stated that trade is one of the key factors promoting economic growth by facilitating capital accumulation, modernization of industrial structure, technological progress, and institutional progress. The majority of studies investigate the effects on the economic growth of both export and import separately but this does not allow evaluating the overall trade balance effect.

Aiming to assess the trade balance impact on economic growth, we focused on all trade balance periods and included only trade balance deficit periods. Evaluating all $28 \mathrm{EU}$ countries shows positive changes in their overall trade balance: gross surplus is increasing and gross deficit is decreasing. Therefore, we can state that the trade balance of EU countries is improving. However, comparing the rates of average trade balance growth and economic growth in both 10 and 20-year cases shows that the situation in $28 \mathrm{EU}$ countries differs, and it could be a cause for the deeper trade balance, or its deficit evaluation.

Our findings are in line with Busse and Königer (2012), Abbas and Raza (2013), Cetintas and Barisik (2008) who suggest that deterioration of trade balance has a negative impact on economic growth or vice versa. The results of multivariate regression analysis (model I) confirm statistically significant negative trade balance impact on economic growth. Analysing the control variables, it was observed that labour variable has a statistically significant positive impact. Also, capital and initial economic growth has a negative impact on economic growth. Commenting on the results of model II and evaluating only trade deficit periods, we confirm a statistically significant negative trade balance impact on economic growth.

Comparing the results of both models, we can state that generally trade balance deterioration reduces average economic growth and from linear relationship evaluation we can state that it does not matter whether it starts from trade deficit or surplus result. When discussing directions for further research, it would make sense to consider other factors as the size of the deficit as well as its permanence. Also, while evaluating the effect on economic growth, we can evaluate the interaction between the trade deficit and its determinants. The results obtained, following Cecen and Xiao (2014), Chen (2011), Wu et al. (2013), may also obscure the possibility of a non-linear effect, which would suggest a stronger negative impact on economic growth when the trade balance deteriorates in the presence of a large trade deficit. The results of both models highlight the need for modelling the inherent nonlinearities in the relationship between export and output growth as well as the impact of deficit size and the factors effecting its impact heterogeneity. Trade policymakers should be concerned about the deteriorating trade balance in countries, not only in deficit but also in surplus.

Author Contributions: Conceptualization, D.B., L.G. and K.M.; methodology, L.G.; formal analysis, D.B. and L.G.; resources, K.M.; data collection D.B. and L.G.; theoretical analysis, K.M.; writing-original draft preparation, D.B., L.G. and K.M.; writing-review and editing, D.B., L.G. and K.M. All authors have read and agreed on the published version of the manuscript.

Funding: This research received no external funding.

Conflicts of Interest: The authors declare no conflict of interest. 


\section{Appendix A}

Table A1. Summary of empirical research on the impact of the trade balance on economic growth.

\begin{tabular}{|c|c|c|c|c|c|c|}
\hline Researcher(s) & Period & Sample & Method * & Trade Variable & $\begin{array}{l}\text { Outcome } \\
\text { Variable }\end{array}$ & Main Results \\
\hline $\begin{array}{l}\text { Michelis and } \\
\text { Zestos (2004) }\end{array}$ & 1950-1990 & $\begin{array}{l}\text { Belgium, France, } \\
\text { Germany, Greece, } \\
\text { Italy, and The } \\
\text { Netherlands }\end{array}$ & $\begin{array}{c}\text { VECM and } \\
\text { Granger-Causality }\end{array}$ & $\begin{array}{l}\text { First logarithmic } \\
\text { differences of } \\
\text { export and } \\
\text { import }\end{array}$ & $\begin{array}{c}\text { First } \\
\text { logarithmic } \\
\text { differences } \\
\text { of GDP }\end{array}$ & $\begin{array}{l}\text { Bi-directional } \\
\text { significant causality } \\
\text { from GDP to exports } \\
\text { and imports }\end{array}$ \\
\hline Awokuse (2007) & 1994-2004 & $\begin{array}{c}\text { Bulgaria, } \\
\text { the Czech } \\
\text { Republic, Poland }\end{array}$ & ECM & $\begin{array}{l}\text { Real exports, } \\
\text { real imports }\end{array}$ & $\begin{array}{l}\text { Real GDP } \\
\text { growth }\end{array}$ & $\begin{array}{l}\text { Significant long-run } \\
\text { causal relationship } \\
\text { from export and } \\
\text { import to GDP }\end{array}$ \\
\hline Awokuse (2008) & 1994-2004 & $\begin{array}{c}\text { Argentina, } \\
\text { Colombia, Peru }\end{array}$ & Granger-Causality & $\begin{array}{l}\text { Real exports, } \\
\text { real imports }\end{array}$ & $\begin{array}{l}\text { Real GDP } \\
\text { growth }\end{array}$ & $\begin{array}{l}\text { Significant causal } \\
\text { effects from imports } \\
\text { to economic growth }\end{array}$ \\
\hline $\begin{array}{l}\text { Cetintas and } \\
\text { Barisik (2008) }\end{array}$ & 1995-2006 & $\begin{array}{l}13 \text { transition } \\
\text { economies }\end{array}$ & $\begin{array}{l}\text { Panel unit root, } \\
\text { panel } \\
\text { cointegration, } \\
\text { panel causality }\end{array}$ & $\begin{array}{l}\text { Export and } \\
\text { import growth }\end{array}$ & GDP growth & $\begin{array}{l}\text { Positive significant } \\
\text { impact of import on } \\
\text { economic growth }\end{array}$ \\
\hline $\begin{array}{c}\text { Sun and } \\
\text { Heshmati (2010) }\end{array}$ & $2002-2007$ & China & SFA, Divisia index & $\begin{array}{l}\text { Net export ratio } \\
\text { and high-tech } \\
\text { exports ratio }\end{array}$ & $\begin{array}{l}\text { Logarithm of } \\
\text { GDP }\end{array}$ & $\begin{array}{l}\text { Significant positive } \\
\text { effect on economic } \\
\text { growth }\end{array}$ \\
\hline $\begin{array}{c}\text { Busse and } \\
\text { Königer (2012) }\end{array}$ & 1971-2005 & 108 countries & OLS, FE, GMM & $\begin{array}{l}\text { Volume of } \\
\text { exports and } \\
\text { imports as a } \\
\text { share of lagged } \\
\text { total GDP }\end{array}$ & $\begin{array}{l}\text { Growth rates } \\
\text { of difference } \\
\text { in the } \\
\text { logarithm of } \\
\text { GDP per } \\
\text { capita }\end{array}$ & $\begin{array}{l}\text { Positive and } \\
\text { significant on } \\
\text { economic growth }\end{array}$ \\
\hline $\begin{array}{c}\text { Fetahi-Vehapi et } \\
\text { al. (2015) }\end{array}$ & 1996-2012 & 10 SEE countries & GMM & $\begin{array}{l}\text { Exports plus } \\
\text { imports to GDP }\end{array}$ & $\begin{array}{l}\text { Logarithm of } \\
\text { real GDP per } \\
\text { capita }\end{array}$ & $\begin{array}{l}\text { Positive significant } \\
\text { effects on economic } \\
\text { growth }\end{array}$ \\
\hline Were (2015) & 1991-2011 & 85 countries & $\begin{array}{l}\text { Standard growth } \\
\text { regression }\end{array}$ & $\begin{array}{c}\text { Exports plus } \\
\text { imports, exports } \\
\text { and imports as a } \\
\text { share of GDP }\end{array}$ & $\begin{array}{l}\text { GDP per } \\
\text { capita } \\
\text { growth }\end{array}$ & $\begin{array}{l}\text { Positive significant } \\
\text { effects of export on } \\
\text { economic growth in } \\
\text { developed countries }\end{array}$ \\
\hline $\begin{array}{l}\text { Altaee et al. } \\
\text { (2016) }\end{array}$ & 1980-2014 & $\begin{array}{c}\text { Kingdom of Saudi } \\
\text { Arabia }\end{array}$ & ARDL, ECM & $\begin{array}{l}\text { Real export, real } \\
\text { import }\end{array}$ & Real GDP & $\begin{array}{l}\text { Export has a positive } \\
\text { impact on economic } \\
\text { growth. Import } \\
\text { affects real GDP } \\
\text { growth negatively }\end{array}$ \\
\hline Bakari (2017) & 1985-2015 & Germany & $\begin{array}{c}\text { VAR, } \\
\text { Granger-Causality }\end{array}$ & $\begin{array}{l}\text { Logarithm of } \\
\text { export and } \\
\text { import }\end{array}$ & $\begin{array}{c}\text { Logarithm of } \\
\text { GDP }\end{array}$ & $\begin{array}{l}\text { Exports and imports } \\
\text { are the source of } \\
\text { economic growth }\end{array}$ \\
\hline $\begin{array}{c}\text { Bakari and } \\
\text { Mabrouki (2017) }\end{array}$ & 1980-2015 & Panama & $\begin{array}{c}\text { VAR, } \\
\text { Granger-Causality }\end{array}$ & $\begin{array}{c}\text { Exports and } \\
\text { imports (current } \\
\text { US\$) }\end{array}$ & $\begin{array}{c}\text { Logarithm of } \\
\text { GDP }\end{array}$ & No effect \\
\hline Keho (2017) & 1965-2014 & Ivory Coast & $\begin{array}{l}\text { ADLB test, VAR, } \\
\text { Granger-Causality }\end{array}$ & $\begin{array}{l}\text { Real export per } \\
\text { capita plus real } \\
\text { import per } \\
\text { capita }\end{array}$ & $\begin{array}{l}\text { Real GDP } \\
\text { per capita }\end{array}$ & $\begin{array}{l}\text { Trade openness is } \\
\text { positively } \\
\text { significantly related to } \\
\text { economic output }\end{array}$ \\
\hline
\end{tabular}


Table A1. Cont.

\begin{tabular}{|c|c|c|c|c|c|c|}
\hline Researcher(s) & Period & Sample & Method * & Trade Variable & $\begin{array}{l}\text { Outcome } \\
\text { Variable }\end{array}$ & Main Results \\
\hline $\begin{array}{l}\text { Bakari and Tiba } \\
\text { (2019) }\end{array}$ & 2002-2017 & $\begin{array}{l}24 \text { Asian } \\
\text { economies }\end{array}$ & FE, RE & $\begin{array}{l}\text { Logarithm of } \\
\text { export and } \\
\text { import (2010 } \\
\text { constant US\$) }\end{array}$ & $\begin{array}{l}\text { Logarithm of } \\
\text { GDP }\end{array}$ & $\begin{array}{c}\text { Negative significant } \\
\text { or no effect }\end{array}$ \\
\hline $\begin{array}{l}\text { Bakari et al. } \\
\text { (2019b) }\end{array}$ & 1970-2017 & Brasilia & VECM & $\begin{array}{l}\text { Logarithm of } \\
\text { export and } \\
\text { import }\end{array}$ & $\begin{array}{l}\text { Logarithm of } \\
\text { GDP }\end{array}$ & $\begin{array}{c}\text { Exports have a } \\
\text { positive significant } \\
\text { effect on economic } \\
\text { growth. } \\
\text { Imports-significant } \\
\text { negative effect }\end{array}$ \\
\hline $\begin{array}{l}\text { Bakari et al. } \\
\text { (2019a) }\end{array}$ & $1960-2015$ & China & $\begin{array}{c}\text { VECM, Granger } \\
\text { Causality }\end{array}$ & $\begin{array}{l}\text { Logarithm of } \\
\text { export and } \\
\text { import }\end{array}$ & $\begin{array}{l}\text { Logarithm of } \\
\text { GDP }\end{array}$ & $\begin{array}{c}\text { Exports have a } \\
\text { positive significant } \\
\text { effect on economic } \\
\text { growth. } \\
\text { Imports-significant } \\
\text { negative effect }\end{array}$ \\
\hline Kumar (2020) & 1990-2016 & $\begin{array}{l}\text { South Asian } \\
\text { Association for } \\
\text { Regional } \\
\text { Cooperation } \\
\text { Countries }\end{array}$ & ARDL & $\begin{array}{l}\text { Import and } \\
\text { export share of } \\
\text { India with } \\
\text { dependent } \\
\text { country }\end{array}$ & $\begin{array}{l}\text { GDP growth } \\
\text { rate }\end{array}$ & $\begin{array}{l}\text { Trade has significant } \\
\text { spillovers on the } \\
\text { economic growth }\end{array}$ \\
\hline
\end{tabular}

* OLS-Ordinary Least Squares; FE—fixed-effects estimation; GMM—generalized method of moments estimator; VAR-Vector Auto Regression Model; ECM-multivariate error correction model with Gaussian errors, RE-random -effects estimation; SFA — stochastic frontier analysis; VECM-Vector Error Correction Model; ARDL-Autoregressive distributed lag model, ECM-Error correction method, ADLB test-Autoregressive Distributed Lag bounds test; ADF test-Augmented Dickey Fuller test; STAR—smooth transition autoregressive model; SYS-GMM—system generalized method of moments estimator.

\section{References}

Abbas, Mohsin, and Hassan Raza. 2013. Effect of trade deficit on the economy of Pakistan. Interdisciplinary Journal of Contemporary Research in Business 4: 176-215.

Akbas, Yusuf E., and Fuat Lebe. 2015. Current Account Deficit, Budget Deficit and Savings gap: Is the twin or triplet deficit hypothesis valid in G7 countries? Prague Economic Papers 25: 271-86. [CrossRef]

Alleyne, Dillon, and Alfred A. Francis. 2008. Balance of payments-constrained growth in developing countries: A theoretical perspective. Metroeconomica 59: 189-202. [CrossRef]

Altaee, Hatem H. A., Mohamed K. Al-Jafari, and Masoud A. Khalid. 2016. Determinants of economic growth in the Kingdom of Saudi Arabia: An application of autoregressive distributed lag model. Applied Economics and Finance 3: 83-92. [CrossRef]

Andersen, Lill, and Ronald Babula. 2009. The link between openness and long-run economic growth. Journal of International Commerce and Economics 2: 31-50.

Apostolakis, George, Nikolaos Giannellis, and Anthanasios Papadopoulos. 2019. Financial stress and asymmetric shocks transmission within the Eurozone. How fragile is the common monetary policy? North American Journal of Economics and Finance 50: 101006. [CrossRef]

Awan, Abdul G., and Sheeza Mukhtar. 2019. Causes of trade deficit and its impact on Pakistan's economic growth. Global Journal of Management, Social Sciences and Humanities 5: 480-98.

Awokuse, Titus O. 2007. Causality between exports, imports, and economic growth: Evidence from transition economies. Economics letters 94: 389-95. [CrossRef]

Awokuse, Titus O. 2008. Trade openness and economic growth: Is growth export-led or import-led? Applied Economics 40: 161-73. [CrossRef]

Awokuse, Titus O., and Dimitris K. Christopoulos. 2019. Nonlinear dynamics and the exports-output growth nexus. Economic Modelling 26: 184-90. [CrossRef]

Bakari, Sayef, and Mohamed Mabrouki. 2017. Impact of exports and imports on economic growth: New evidence from Panama. Journal of Smart Economic Growth 2: 67-79. 
Bakari, Sayef, and Sofien Tiba. 2019. The Impact of Trade Openness, Foreign Direct Investment and Domestic Investment on Economic Growth: New Evidence from Asian Developing Countries. MRPA Paper 94489. Available online: https://mpra.ub.uni-muenchen.de/94489/1/MPRA_paper_94489.pdf (accessed on 15 December 2019).

Bakari, Sayef, Fatma Saaidia, and Ahlem Soualhia. 2019a. Evaluation of Trade Influence on Economic Growth in China: A Time Series Analysis. Journal of Smart Economic Growth 4: 57-72.

Bakari, Sayef, Nissar Fakraoui, and Sofien Tiba. 2019b. Domestic Investment, Export, Import and Economic Growth in Brazil: An Application of Vector Error Correction Model. MPRA Paper 95528. Available online: https://mpra.ub.uni-muenchen.de/95528/1/MPRA_paper_95528.pdf (accessed on 10 December 2019).

Bakari, Sayef. 2017. Trade and Economic Growth in Germany. LIEI, Faculty of Economic Sciences and Management of Tunis (FSEGT). MPRA Paper No. 77404. Available online: https://mpra.ub.uni--muenchen.de/77404/1/MPR A_paper_77404.pdf (accessed on 30 November 2019).

Busse, Matthias, and Jens Königer. 2012. Trade and Economic Growth: A Re-Examination of the Empirical Evidence. Available online: http://dx.doi.org/10.2139/ssrn.2009939 (accessed on 10 December 2019).

Butkus, M., and J. Seputiene. 2018. Growth Effect of Public Debt: The Role of Government Effectiveness and Trade Balance. Economies 6: 62. [CrossRef]

Cecen, Aydin, and Linlan Xiao. 2014. Capital flows and current account dynamics in Turkey: A nonlinear time series analysis. Economic Modelling 39: 240-46. [CrossRef]

Cetintas, Hakan, and Salih Barisik. 2008. Export, Import and Economic Growth: The Case of Transition Economies. Transition Studies Review 15: 636-49. [CrossRef]

Chen, Shyh-Wei. 2011. Current account deficits and sustainability: Evidence from the OECD countries. Economic Modelling 28: 1455-64. [CrossRef]

Cooper, Richard N. 2007. Why a large US deficit is likely to persist. CESifo Forum 8: 6-11.

Fetahi-Vehapi, Merale, Luljeta Sadiku, and Mihail Petkovski. 2015. Empirical analysis of the effects of trade openness on economic growth: An evidence for South East European Countries. Procedia Economics and Finance 1: 17-26. [CrossRef]

Gabberty, James W., and Robert G. Vambery. 2014. Trade Deficits Always Matter. International Business and Economics Research Journal 13: 371-76. [CrossRef]

Garcimartin, Carlos, Virmantas Kvedaras, and Luis Rivas. 2016. Business cycles in a balance-of-payments constrained growth framework. Economic Modelling 57: 120-32. [CrossRef]

Goldin, Claudia. 2016. Human Capital. In Handbook of Cliometrics. Edited by Claude Diebolt and Michael Haupert. Heidelberg: Springer, pp. 55-86.

Hsiao, C. 2003. Analysis of Panel Data, 2nd ed. Cambridge: Cambridge University Press.

Kang, Joong S., and Jay C. Shambaugh. 2016. The rise and fall of European current account deficit. Economic Policy 31: 153-99. [CrossRef]

Keho, Yaya. 2017. The impact of trade openness on economic growth: The case of Cote d'Ivoire. Cogent Economics and Finance 5: 1-14. [CrossRef]

Kumar, Rakesh. 2020. India and South Asia: Geopolitics, regional trade and economic growth spillovers. The Journal of International Trade and Economic Development 29: 69-88. [CrossRef]

Kvedaras, Virmantas, Carlos Garcimartín, and Jhonatan Astudillo. 2020. Balance-of-Payments constrained growth dynamics: An empirical investigation. Economic Modelling 89: 232-44. [CrossRef]

Malik, U., S. Noor, S. Jahangir, N. Tariq, A. Ramzan, and R. Fatima. 2015. The Trade Balance of Pakistan and Its Impact on Exchange Rate of Pakistan: A Research Report. Journal of Economics and Sustainable Development 6: 1-10.

Marfatia, Hardik, Wan-Li Zhao, and Qiang Ji. 2020. Uncovering the global network of economic policy uncertainty. Research in International Business and Finance 53: 101223. [CrossRef]

Marfatia, Hardik. 2016. The Role of Push and Pull Factors in Driving Global Capital Flows. Applied Economics Quarterly 62: 117-46. [CrossRef]

Marfatia, Hardik. 2020. Evaluating the forecasting power of foreign Country's income growth: A global analysis. Journal of Economic Studies. [CrossRef]

Michelis, Leo, and George K. Zestos. 2004. Exports, imports and GDP growth: Causal relations in six European Union countries. The Journal of Economic Asymmetries 1: 71-85. [CrossRef]

Papadimitriou, Dimitri B., Greg Hannsgen, and Gennaro Zezza. 2008. The Buffett Plan for Reducing the Trade Deficit. The Levy Economics Institute of Bard College Working Paper 538: 1-39. [CrossRef] 
Soukiazis, Elias, Eva Muchova, and Pedro A. Cerqueira. 2014a. Is the Slovak Economy Doing Well? A Twin Deficit Growth Approach (No. 2014-08). Coimbra: University of Coimbra.

Soukiazis, Elias, Micaela Antunes, and Ioannis Kostakis. 2018. The Greek economy under the twin-deficit pressure: A demand orientated growth approach. International Review of Applied Economics 32: 215-36. [CrossRef]

Soukiazis, Elias, Pedro A. Cerqueira, and Micaela Antunes. 2012. Modelling economic growth with internal and external imbalances: Empirical evidence from Portugal. Economic Modelling 29: 478-86. [CrossRef]

Soukiazis, Elias, Pedro A. Cerqueira, and Micaela Antunes. 2014b. Explaining Italy's economic growth: A balance-of-payments approach with internal and external imbalances and non-neutral relative prices. Economic Modelling 40: 334-41. [CrossRef]

Sun, Peng, and Almas Heshmati. 2010. International Trade and its Effects on Economic Growth in China. IZA Discussion Paper 5151. Available online: https://ssrn.com/abstract=1667775 (accessed on 15 December 2019).

Thirlwall, Anthony P. 1979. The balance of payments constraint as an explanation of the international growth rate differences. PSL Quarterly Review 32: 45-53.

Topalli, Nurgun, and Ibrahim Dogan. 2016. The structure and sustainability of current account deficit: Turkish evidence from regime switching. Journal of International Trade and Economic Development 25: 570-89. [CrossRef]

Velnampy, Thirunavukkarasu, and Sivapalan Achchuthan. 2013. Export, import and economic growth: Evidence from Sri Lanka. Journal of Economics and Sustainable Development 4: 147-55.

Wagner, Joachim. 2007. Exports and productivity: A survey of the evidence from firm level data. The World Economy 30: 60-82. [CrossRef]

Were, Maureen. 2015. Differential effects of trade on economic growth and investment: A cross-country empirical investigation. Journal of African Trade 2: 71-85. [CrossRef]

Wu, Po-Chin, Shiao-Yen Liu, and Sheng-Chieh Pan. 2013. Nonlinear bilateral trade balance-fundamentals nexus: A panel smooth transition regression approach. International Review of Economics \& Finance 27: 318-29.

(C) 2020 by the authors. Licensee MDPI, Basel, Switzerland. This article is an open access article distributed under the terms and conditions of the Creative Commons Attribution (CC BY) license (http://creativecommons.org/licenses/by/4.0/). 